\title{
Dilated ascending aorta: is reductive ascending aortoplasty really forgotten?
}

\author{
Z Jonjev ${ }^{*}$, M Rosic, B Mihajlovic, A Redzek, M Fabri \\ From 23rd World Congress of the World Society of Cardio-Thoracic Surgeons \\ Split, Croatia. 12-15 September 2013
}

\section{Background}

Patients with dilated ascending aorta require surgical correction due to increased risk for aortic dissection and/or rupture. However, there is a controversy whether the dilated ascending aorta should be replaced with prosthetic graft or reduced by reductive ascending aortoplasty (RAA). The aim of this study is to analyze our results with "cut and sew" unwrapped RAA.

\section{Method}

There were 25 pts operated on from 2002 to 2013. The average size of aorta was $5.5 \pm 0.4 \mathrm{~cm}$, and most of the patient had concomitant aortic valve stenosis or insufficiency. All patients were treated with unwrapped RAA.

\section{Results}

There was no postoperative (30 days) mortality. The average size of reduced aorta was $3.4 \pm 0.3 \mathrm{~cm}$. There was no significant postoperative bleeding or other major immediate morbidities. Most of the patients had abnormal histological finding of the aortic wall specimen. Recurrence rate after 10 years follow up was $4.5 \%$ (1pt).

\section{Conclusion}

Unwrapped RAA procedure could be successfully applied in selective, preferable older patients with dilation of ascending aorta. However, prosthetic graft implantation is recommended in patients where rapid recurrent aortic dilation is expected.

Published: 11 September 2013

* Correspondence: jonjevz@nscable.net

Institute for CVD of Vojvodina, Sremska Kamenica, Serbia
doi:10.1186/1749-8090-8-S1-P6

Cite this article as: Jonjev et al:: Dilated ascending aorta: is reductive ascending aortoplasty really forgotten? Journal of Cardiothoracic Surgery 2013 8(Suppl 1):P6.
Submit your next manuscript to BioMed Central and take full advantage of:

- Convenient online submission

- Thorough peer review

- No space constraints or color figure charges

- Immediate publication on acceptance

- Inclusion in PubMed, CAS, Scopus and Google Scholar

- Research which is freely available for redistribution 